colleges, a whole array of "literature" and "cultural studies" courses continue to be taught and to generate faculty positions. But the model in question is, as Sullivan complains, a top-down one, and I agree that it is time to pay attention to the "activist bottom." Indeed, Sullivan will be happy to hear that Gerald Graff, the 2008 MLA president, whose fields of specialization include composition theory and the pedagogy of English teaching, plans to focus on precisely the issues Sullivan has in mind.

Marjorie Perloff Stanford University

\section{The University and Class Warfare}

\section{To THE EDITOR:}

I was pleased to see Stephen Schryer's contribution, in "Fantasies of the New Class: The New Criticism, Harvard Sociology, and the Idea of the University" (122 [2007]: 663-78), to a revival of interest in postwar American sociological scholarship, and I found his comparison between that scholarship and the New Criticism convincing. I was particularly pleased by his consideration of Alvin Gouldner's The Future of Intellectuals and the Rise of the New Class, a work of critical theory whose important implications for humanistic study have never received sufficient attention. My only qualification is to ask whether Schryer might have been too quick to present the book as typical of Parsonian, "Harvard" sociology. Gouldner was among the New Left sociologists who rebelled against that school, and his position was distinctive as an audacious alternative both to it and to leftist critiques of it.

Schryer is correct in pointing to Gouldner's glaring "failed prophec[y]"-his 1979 interpretation of Ronald Reagan's failure to win the 1976 Republican presidential nomination as a sign of the replacement of the old ruling class of "the moneyed bourgeoisie" by the "new social order of professionals, centered in the university, that would extend and perfect the United States welfare state" (663). As Schryer sadly notes, with Reagan's reemergence in 1980, the old class "found a powerful voice within the New Right and the rejuvenated Republican party, which gutted what was left of the welfare state and launched an all-out attack on the educated liberal morality of the intellectuals" (664). This attack has continued unabated through recent jihads like David Horowitz's Academic Bill of Rights and Republicans' ridicule of John Kerry's French looks or Al Gore's scholarly demeanor. Whether or not the attack has shot its wad and will recede before a renewal of liberal politics and public policy is a key question of the present moment.

My sense is that the "new social order of professionals ... that would extend and protect the United States welfare state," extolled by social scientists in the 1950s and 1960s, may have had it right, at least more than was granted by those who savaged them from both the right and left (even though the social scientists' agenda contained a large dose of selfpromotion). From today's vantage point, much more, not less, implementation of the welfare state, especially in programs like the War on Poverty, would undeniably have been a preferable alternative.

As for Gouldner, perhaps his failed prophecy can be partly redeemed by viewing it as an inadvertent confirmation of his case that humanistic New Class intellectuals, "while morally ambiguous, may still be the best card history has dealt"-especially for the political left, which has been pummeled by reactionism from Reagan to George W. Bush. In a chapter titled "The New Class as a Speech Community," Gouldner develops the notion of "the culture of critical discourse" (CCD), his acknowledged variation on the sociolinguist Basil Bernstein's "elaborated code," as the defining trait of humanistic intellectuals (as opposed to the technocratic ones, who are a rival branch of the New Class). Gouldner was among the many modern leftists who reluctantly lost hope in the revolutionary possibilities of the working class, for reasons including Bernstein's accounts of the cognitive and discursive restrictions contempo- 
rary mass society imposes on the poor and on blue-collar workers. It is up to progressive educators and other intellectuals, then, to maintain a critical consciousness of, and opposition to, the social forces perpetuating those restrictions and to seek means of enabling students and other citizens, whatever their class identity, to evolve from restricted to elaborated codes.

Gouldner, who came out of a Marxist background, takes account of Marx's theory of ideology, according to which the ideas that serve the interests of the ruling class are imposed on subordinate classes and assumed to be the natural, commonsensical way things are. "What's good for General Motors is good for America." While not denying an element of self-interest in the New Class's thinking, Gouldner argues that what is good for the New Class is good for everyone. CCD is intrinsically not only ideologically neutral but a defense against ideological domination by anyone. "It subverts all establishments, social limits, and privileges, including its own. The New Class bears a culture of critical and careful discourse which is an historically emancipatory rationality."

Thus, if the CCD were attainable through education and cultural media to everyone in society, the New Class would in effect become a "universal class," a new basis for Marx's classless society, facilitated through the common interests of the working class, middle class, and intellectuals, against capitalist hegemony, with the CCD as a lingua franca. As Gouldner acknowledges, his arguments are akin to those of Jürgen Habermas, who Gouldner says seeks "a new institutional framework - the 'ideal speech situation'-within which not only technical means might be chosen, but which would also revitalize morality."

Gouldner refutes leftists who depict universities as monolithically conservative: "To understand modern universities and colleges, we need an openness to contradiction. For universities both reproduce and subvert the larger society.... While the school is designed to teach what is adaptive for the society's master institutions, it is also often hospitable to a culture of critical discourse by which authority is unwittingly undermined, deviance fostered, the status quo challenged, and dissent systematically produced."

Neither Gouldner nor I go so far as to imagine academic intellectuals as a revolutionary vanguard, and both of us are fully aware of their political limitations. However, in this age of globalization, in which the working class and unions have largely been disarmed and in which millions of the middle class have been proletarianized, perhaps our overly modest class-as one of the last remaining guardians of cognitive and discursive alternatives to the new global order-is indeed, faute de mieux, "the best card history has dealt." And who knows, maybe we can even recuperate the New Critics' distinctive, aesthetic conception of the culture of critical discourse for progressive pedagogy.

Donald Lazere

University of Tennessee, Knoxville

\section{To THE EDITOR:}

I have two questions for Stephen Schryer, whose "Fantasies of the New Class: The New Criticism, Harvard Sociology, and the Idea of the University" convincingly aligns the evolution of John Crowe Ransom's ideas about literary studies and those of Talcott Parsons about sociology.

First, to what extent does Schryer think these two shifts can stand for trouble in the professions as a whole and in the new class that they and some managers hoped to constitute? He proposes that "Parsons's sociology and the New Criticism" represented "disciplinary consensuses" that "lasted to the mid-1960s" (675). That's already a lot for them to represent, especially if Schryer sees that consensus in most or all academic disciplines. But if, as he further suggests, the failure of Alvin Gouldner's 1979 prediction-that the new elite would replace the "capital-owning bourgeoisie"-owes to an internal "logic of specialization," which, "instead of binding together the new class, atomized it into a concatenation of disciplines," then 